\title{
Book Review: Aullón de Haro, P. (ed.) (2010). Teoría del Humanismo. Madrid: Verbum, 7 Vols. + DVD.
}

\author{
Esther Zarzo \\ Department of Spanish studies \\ University of Alicante, Spain
}

Received: 28-09-2014

doi:10.7575/aiac.ijclts.v.2n.4p.40
Accepted: 25-10- 2014

Published: $31-10-2014$

Teoria del Humanismo is made up of seven volumes and an accompanying DVD version, and is the result of a project conceived by the Research Group "Humanismo-Europa" directed by Prof. Pedro Aullón de Haro from the University of Alicante, Spain, with the collaboration of Medialab-Prado, a state-of-the-art research center in Madrid. This project has involved approximately one hundred and fifty participants from across a wide range of geographical locations, as well as from diverse linguistic and academic contexts in order to rebuild and reinterpret the idea of historical Humanism while also trying to respond to the current humanistic crisis.

As far as its academic projection is concerned, after the structural-formalist positivization that was carried out throughout the 20th century, to a large extent Humanism has been relegated to a syllabus that gives diminishing importance to humanistic sciences in comparison to other technical knowledge. It is also being implicitly minimized, not only from public administrations, but also from certain epistemological scopes. A piece of work, whose objective was to liberate the everlasting basis of humanism, was becoming essential, in order to organise the diverse disciplines and arts that are part of human knowledge, and to lay the foundations of humanistic criteria for our future.

Therefore, Teoria del Humanismo is the expression of a commitment which reveals not only the ethical and intellectual disobedience against the neutralization of the liberating potential of our cultural heritage, but also the drive and responsibility to recover a project for immediate action on the grounds of a traditional humanistic conception focused on mankind and culture. The aim is to propose a fulfilling way of life, both in theory and practice, based on dignity and conducive to human evolution through precise epistemological and ethical education. This is an ideal approach, not from a human nature point of view, but as a conquest of the spirit that is supposed to be universal to all fields of knowledge, as it concerns fundamental aspects of the subject and object of the most important cultures from Asia to Europe.

The work was designed, synthetically assuming the already known argument, with the purpose of exploring and addressing important fields that, until the present day, have not been addressed, and if so, only partially. For this reason the work includes many different kinds of articles. Indeed, we find expositive works, mainly those of original research, but also those of reconstruction and balance; and those of synthesis and historic or disciplinary reinterpretation; apart from approximately fifteen contemporary classic texts that are fully included since they solved theoretical aspects of great importance, as is the case of the selected texts from Wilhelm Dilthey, Wilhelm von Humboldt, Miguel de Unamuno, Xavier Zubiri, María Zambrano, Jiddu Krishnamurti, Carl Gustav Jung, Manuel García Morente, Alfonso Reyes, Ernst Cassirer and George Voigt.

Given the great diversity of issues covered, from digital to artistic, literary, philosophical, philological, scientific matters as well as Personalistic, Krausist or Indigenist tendencies, a comparative and transdisciplinary methodological approach has been adopted. Hence, we resort to humanistic elaborations in the fields of philology, philosophy, theology, psychology, pedagogy, political science and medicine and the arts (cinema, photography, plastic arts, visual arts and literary genres).

In general, as stated in the Preface to the collection, the work is organized into two main parts. The first has an epistemological nature that covers the first three volumes; the second is more historical in its orientation and is made up of the four remaining volumes. The first part is devoted to the idea of Humanism in itself and its disciplinary materializations, predominantly those of a more contemporary and current persuasion; and the second is dedicated to the exploration of the profile of the entire humanistic universe, ending with a thematic conciliatory and evolutionary organization and projecting its asymptotic closure in the future.

The general plan of the work can be inferred from the summary of its first chapter. 1. Definition of Humanism, of Universal Humanism and its historic anchoring inside civilizations; 2. Historic specifications of Humanism and its transmission to Christian culture, as well as Asiatic and Hebraic cultures; 3. Aspects of the evolution of the Humanism and human sciences; 4 . The ethical concept of Humanism and the problem of its own dissolution and to the rest of the human sciences, particularly due to the strong structural-formalist aggression during the 20th century; 5 . The current problem of academic institutions and its relationship with human sciences and Humanism; 6. Europe as a cultural entity 
and a humanistic paradigm; 7. The general regime of the civilizations, the dialectic Asia-West and the current problem of globalization.

After the first chapter written by the editor, theoretical and epistemological founder, Pedro Aullón de Haro, the collection offers three more introductory chapters on terminological revision, on encyclopedic transmission and on the history of culture and of Humanism, respectively, all of which offer the necessary context to reach and understand (in the fifth chapter, written by Raimon Panikkar) the historic and foundational moment of the humanistic impulse. In his essay "La mutación de la conciencia en el siglo de Buddha" (vol. I, pp. 199-216) Panikkar describes the revolution of human consciousness that takes place around the 6th century $\mathrm{BC}$, largely due to the shift from the cosmologic paradigm into the anthropologic one, on the one hand, and to the activation of individual and free consciousness as the core idea of the world and of ethical action and speculative thought, on the other. On this basis, and given that language is an attribute that humans take for granted, linguistic condition became the core of humanistic discourse in Europe.

The editor devotes an entire chapter to the humanistic theory of language (vol. I, pp. 445-481), in which language is defined as both the access to, and the main object of, humanistic work. This is because it represents (beyond any historical-cultural particularities) the expression of the self's internal conquest of humanity, whether on a moral, cognitive, creative or/and communicative level.

In a very valuable reinterpretation of classic Ciceronian themes, José Joaquín Caerols (vol. IV, pp. 113-152) offers the formative archetype of the Humanitas Latina, continuator of the Greek paideia, according to which the development of a civilized spirit, both in an individual and a collective sense, entails the instruction of knowledge and moral values. Then the pendulum-like rise-and-decline of this ideal is analysed. Firstly, within both the medieval humanistic crisis and the Renaissance recovery of Humanism with the philological edition of the Greek-Latin works in vernacular languages, which allowed for the humanistic axiology to become part of Christianity; then, the modern disintegration of Humanism with the expansion of the Cartesian conception of language as a tool for all that is universal and for clarity of thought, which led to the separation between rationalism and humanism - the first one triumphing throughout the 20th century and leading to contemporary linguistic positivisms, to the anti-humanist scientificism and to our current impoverished instrumental pedagogy. And we must not forget the 18th century, the illustrious antecedent of 19thcentury German Neo-humanism which materialized in the theoretical reconfigurations of Winckelmann, Lessing and Schiller that culminate in the philological work of Werner Jaeger (vol. I, pp. 385-411), a work only to be compared to the literary and theoretical writings of Ernst Robert Curtius.

Consciously located within the age of globalization, Teoria del Humanismo therefore intends to inherit the humanistic western tradition and relocate it in a universal framework, that is, incorporating the Asian world. Thus, while it is true that in eastern cultures the humanistic impulse was linked to moments of transformation in the religious sphere, it is equally so for classical Greco-Roman humanism, which incorporated the divine factor in the explanation of humanity. In fact, the separation between the religious and the secular space is a consequence of the political and religious divorce between the Papal and Imperial powers that started in the 13th century and that was (at least, theoretically) fully developed in the Age of Enlightenment. This means that the image of classic societies as radically anthropocentric and self-sufficient -with respect to divinity- is a partially distorted modern vision of the ancient Greco-Roman society.

That being said, we must remember that in order to articulate a fruitful convergence we must determine the elements to be compared. This task is consciously undertaken throughout Teoría del Humanismo, which specifies the universal humanistic principle and epistemologically rebuilds its diverse manifestations in a systematic manner. Hence, if we adopt a geographical organization, we can say that Teoría del Humanismo rebuilds asian humanism in its consideration of the particularities of hindu, chinese, korean, japanese and philippine humanisms. "El humanismo en Filipinas" (vol. VI, pp. 283-328) written by Isaac Donoso describes the evolution of Philippine thought from the 16th century up to the present, and in accordance with Fernando Ziálcita, promotes cooperation throughout the Asian-Pacific region, not only economically, but also culturally, in order to articulate a modern and comprehensive cultural identity, where the australian particularity plays an important role. Cuban, mexican, and the most modest puertorican humanisms are also considered.

At the same time islamic and african philological humanisms are explored, together with the humanistic traditions of Russia, Poland, the Czech Republic and Romania, leaving a separate space for jewish humanism, which is still dispersed throughout several geographical places and thus submitted within the history of its culture. Finally, the cases of Spain, France, Portugal and modern Italy are addressed in a select and interrelated manner.

Obviously, we cannot offer a detailed description of every single chapter in the collection. We can sum up by saying that Teoría del Humanismo intends to locate the universality of humanistic principles in all cultures; but the collection also works as an axiological treatise inasmuch as it presupposes the self-awareness of humans and their ideas of humanity. The human being as an entity differentiated from nature and characterized by their ability to use language, which is essential to our ethical, pedagogical and cognitive development and the universal point of confluence that provides us with a margin for the convergence between what is different and what is similar, and consequently, with the opportunity to create a new foundation for globalization - which has hitherto been approached only in terms of trade and communication and transport technologies- via humanistic values conducive to the achievement of a fulfilling life, understood as the practice of a theory rooted in both tradition and in its endless reinterpretation. In short, Teoria del Humanismo intends to provide not only knowledge, but also to work with the intention of creating another destiny. 